\title{
集中質量を有する Mindlin 平板の自由振動解析 FREE VIBRATION ANALYSIS OF MINDLIN PLATES WITH A LUMPED MASS
}

\author{
内山武司*1, 上田正生*2, 大家 史*3 \\ Takeshi UCHIYAMA, Masaiki UEDA and Fumito OYA
}

\begin{abstract}
Based on Mindlin's plate theory, it is presented a free vibration analysis of plates with a lumped mass. By using the method of superimposition, it is shown that solutions which satisfy both the differential equation and the boundary condition are obtained. The rectangular plates under consideration are as follows : a) all edges simply supported and b) all edges built-in. Eigenvalues of four digit accuracy are provided for a wide range of plate aspect ratio. Numerical results are compared with those by Rayleigh-Ritz method and interpolative values using Dunkerley's equation, to verify the accuracy of the proposed method.
\end{abstract}

Keywords : free vibration, Mindlin's plate, lumped mass, superimosition method, Rayleigh-Ritz method, Dunkerley's equation, eigenvalue 自由振動、Mindlin平板、集中質量、重称合せ法、Rayleigh-Ritz法、Dunkerley式、固有值

\section{1.はじめに}

平板の曲げ振動理論は、Kirchhoff仮定に基づく古典理論と、剪 断変形と回転慣性を考慮したMind lin理論 ${ }^{11}$ に大別される。平板の 曲げ自由振動解析として代表的なものとして、D.J.Gorman ${ }^{2)}$ の重ね 合せ法を用いた古典理論解があり、種々の境界条件を有する長方形 平板について系統的に固有振動数とモード形状を求め、ほぼ整備さ れた状態にある。他方、Mindlin平板の自由振動解についても、筆 者等 ${ }^{3-8)}$ が各種の境界条件を有する長方形板を対象に、重社合せ法 を使用した級数解を求めてきた。これとは別個に、K. M. L i ew等 ${ }^{8)} も$ 代数関数を使用したRitz解を求めている。これ等の自由振動解析に 共通していることは、固有振動解に影響を及ぼす重要な因子の一つ である質量分布を平板内で一定、即ち一様分布質量を前提にしてい ることである。実際の構造物の床スラブ等では、積載荷重が偏在す ることもあり質量分布が非一様分布となる場合がある。このような ことをD.J.Gormanも指摘しているが、筆者等の知る限り、質量分布 が偏在したり集中する場合の解は提示されていないようである。

本報告は、平板の質量が自重のように一様分布するのに加え、積 載荷重等が集中する場合を想定し、固有振動解に及ぼす集中質量の 影響を検討するものである。解析方法は、既報告 ${ }^{8)}$ の「点支持を有 するMindlin平板の自由振動解析」に倣い、周辺単純支持と周辺固
定の両長方形平板について、重站合せ法を用いた級数解を求めると 共に、代数関数を使用したRayleigh一Ritz解との比較から、提示し た解析方法の妥当性を検討したものである。また、集中質量が平板 の基本振動数に及ぼす影響をDunkerley式(0)を利用した補間式で近 似的に推定できることを確認し、集中質量を伴った周辺単純支持板 と周辺固定板の振動特性を明らかにしたものである。

\section{2. 基礎微分方程式と境界条件}

2.1）基礎微分方程式

平板の自由振動方程式で、平板中央面の変位成分を

$x$ 方向 : $U(x, y, z, t)=z \cdot \theta_{x}(x, y) \cdot \cos \omega t$

$y$ 方向 : $\quad V(x, y, z, t)=z \cdot \theta_{y}(x, y) \cdot \cos \omega t$

$z$ 方向 : $\quad W(x, y, z, t)=w(x, y) \cdot \cos \omega t$

但し、 $\theta_{x}, \theta_{y}, w: x, y$ 方向の回転角、 $z$ 方向の変位

$\omega, t$ : 角振動数、時間

とおくと、平板の中央面に重直な方向の分布荷重 $q(x, y, t)$ が作用 する場合、剪断変形と回転慣性の効果を考慮した平板の自由振動に 関する基礎微分方程式が得られる”。

$$
\frac{D}{2}\left\{\nu_{1} \triangle \theta_{x}+\nu_{2} \frac{\partial \Phi}{\partial x}\right\}-\kappa G h\left(\frac{\partial w}{\partial x}+\theta_{x}\right)+\frac{\omega^{2} \rho h^{3}}{12} \theta_{x}=0
$$

*1 北海道大学大学院工学研究科社会基盤工学専攻 教授・工博

*2 北海道大学大学院工学研究科社会基盤工学尃攻 助教授・王博

*3 北海道大学大学院—学研究科社会基盤○学尃攻 大学院生
Prof., Graduate School of Hokkaido Univ., Dr. Eng. Assoc. Prof., Graduate School of Hokkaido Univ., Dr. Eng. Graduate Student, Graduate School of Hokkaido Univ. 


$$
\frac{D}{2}\left\{\nu_{1} \triangle \theta_{y}+\nu_{2} \frac{\partial \Phi}{\partial y}\right\}-\kappa G h\left(\frac{\partial w}{\partial y}+\theta_{y}\right)+\frac{\omega^{2} \rho h^{3}}{12} \theta_{y}=0
$$

$\kappa G h(\triangle w+\Phi)+\omega^{2} \rho h w+q=0$

但し、 $D=E h^{3} / 12\left(1-\nu^{2}\right), \quad \nu_{1}=1-\nu, \quad \nu_{2}=1+\nu$

$\triangle=\partial^{2} / \partial x^{2}+\partial^{2} / \partial y^{2}, \quad \Phi=\partial \theta_{x} / \partial x+\partial \theta_{y} / \partial y$

$E, G, \nu$ : ヤング係数、剪断弾性係数、ポアソン比

$\rho, h, \kappa$ : 密度、板厚、剪断補正係数

また、平板の内部に生ずる曲げ・㨝りモーメント $M_{x}, M_{y}, M_{x y}$ と剪 断力 $Q_{x}, Q_{y}$ は、既報告 ${ }^{3}$ に記した通りである。

平板上に位置する集中質量 $M$ の変位成分 ${ }_{M} W$ は、平板と同位相で 振動することから、次のように表示できる。

$$
{ }_{M} W={ }_{M} W \cdot \cos \omega t
$$

従って、集中質量の慣性力による集中荷重 $P$ は、

$$
P=M \omega^{2} \cdot M \omega \cdot \cos \omega t
$$

で表される。

\section{2) 境界条件と連続条件}

周辺単純支持と周辺固定の両平板の座標を図-1のように設定する

と、境界条件は無次元化した座標表示で次のようになる。

周辺単純支持板 ${ }^{3)}$ :

$$
\begin{aligned}
& w(0, \eta)=M_{x}(0, \eta)=M_{x y}(0, \eta)=0 \\
& w(1, \eta)=M_{x}(1, \eta)=M_{x y}(1, \eta)=0 \\
& w(\xi, 0)=M_{y}(\xi, 0)=M_{x y}(\xi, 0)=0 \\
& w(\xi, 1)=M_{y}(\xi, 1)=M_{x y}(\xi, 1)=0
\end{aligned}
$$

周辺固定板 ${ }^{2)}$ :

$$
\begin{aligned}
& w(0, \eta)=\theta_{x}(0, \eta)=\theta_{y}(0, \eta)=0 \\
& w(1, \eta)=\theta_{x}(1, \eta)=\theta_{y}(1, \eta)=0 \\
& w(\xi, 0)=\theta_{x}(\xi, 0)=\theta_{y}(\xi, 0)=0 \\
& w(\xi, 1)=\theta_{x}(\xi, 1)=\theta_{y}(\xi, 1)=0
\end{aligned}
$$

また、集中質量の変位は、平板との接触問題となることから、次の うになる。

$$
M^{\prime} w=w\left(\xi_{M}, \eta_{M}\right)
$$

但し、 $\xi_{M}, \eta_{M}$ : 集中質量の作用する無次元化した座標位置

\section{3．集中質量を有する平板の固有振動解}

3. 1) 非斉次解

集中質量の作用する位置で、集中荷重 $P$ をフリエ級数で表示す ると、次のようになる。

$q(\xi, \eta, t)=\frac{4 P}{a^{2} \phi} \sum_{m=1}^{\infty} \sum_{n=1}^{\infty} \sin \mu_{m} \xi_{M} \sin \mu_{n} \eta_{M} \cdot \sin \mu_{m} \xi \sin \mu_{n} \eta \cdot \cos \omega t$

但 $、, \phi=b / a, \mu_{m}=m \pi, \quad \mu_{n}=n \pi, \quad m, n=1,2,3, \cdots$

こ扎から、変位成分に関する非斉次解は、以下となる ${ }^{81}$ 。

$$
\begin{aligned}
& \alpha \omega=\frac{4 P a^{2}}{\phi D} \sum_{m=0}^{\infty} \sum_{n=0}^{\infty} \frac{L_{m n} \sin \mu_{m} \xi \sin \mu_{n} \eta}{\left(\mu_{m}^{2}+\alpha_{n}^{2}-\Omega_{1}\right)\left(\mu_{m}^{2}+\alpha_{n}^{2}-\Omega_{2}\right)} \\
& \theta_{x}=\frac{4 P a}{\phi D} \sum_{m=1}^{\infty} \sum_{n=1}^{\infty} \frac{\Theta_{x m n} \cos \mu_{\xi} \sin \mu_{n} \eta}{\left(\mu_{m}^{2}+\alpha_{n}^{2}-\Omega_{1}\right)\left(\mu_{m}^{2}+\alpha_{n}^{2}-\Omega_{2}\right)} \\
& \theta_{y}=\frac{4 P a}{\phi D} \sum_{m=1}^{\infty} \sum_{n=1}^{\infty} \frac{\Theta_{y m n} \sin \mu_{\xi} \cos \mu_{n} \eta}{\left(\mu_{m}^{2}+\alpha_{n}^{2}-\Omega_{1}\right)\left(\mu_{m}^{2}+\alpha_{n}^{2}-\Omega_{2}\right)}
\end{aligned}
$$

但し、 $\alpha_{n}=\mu_{n} / \phi, \quad \lambda^{2}=\omega^{2} \rho h a^{4} / D$

$$
L_{m n}=\left\{1+\frac{\mu_{m}^{2}+\alpha_{n}^{2}}{6 \nu_{1} \kappa} \frac{h^{2}}{a^{2}}-\frac{\lambda^{2}}{72 \nu_{1} \kappa} \frac{h^{4}}{a^{4}}\right\} \sin \mu_{m} \xi_{M} \sin \mu_{n} \xi_{M}
$$


図-1＼cjkstart平板の全体座標と無次元化座標

$\Theta_{x m n}=\mu_{m} \sin \mu_{m} \xi_{M} \sin \mu_{n} \eta_{M}, \quad \Theta_{y m n}=\alpha_{n} \sin \mu_{m} \xi_{M} \sin \mu_{n} \eta_{M}$ $\Omega_{1,2}=\frac{\lambda^{2}\left(2+\nu_{1} \kappa\right)}{24 \nu_{1} \kappa} \frac{h^{2}}{a^{2}} \pm \sqrt{\lambda^{2}+\frac{\lambda^{4}\left(2-\nu_{1}\right) \kappa}{576 \nu^{2} \kappa^{2}} \frac{h^{4}}{a^{4}}}$

但し、 $\Omega_{1}$ は正符号、 $\Omega_{2}$ は負符号である。

これは、周辺単純支持と固定の両平板について共通した境界条件

$$
w(0, \eta)=w(1, \eta)=w(\xi, 0)=w(\xi, 1)=0
$$

を満たしている。

3.2) 斉次解

斉次解は、境界条件 (10) の他に、周辺単純支持板について、

$$
M_{x}(0, \eta)=M_{x}(1, \eta)=M_{y}(\xi, 0)=M_{y}(\xi, 1)=0
$$

また、周辺固定板について、

$$
\theta_{x}(\xi, 0)=\theta_{x}(\xi, 1)=\theta_{y}(0, \eta)=\theta_{y}(1, \eta)=0
$$

の条件を充足する斉次解は、次の形で得られる。

$$
\begin{aligned}
& { }_{1} w=\frac{a^{2}}{D}\left[\sum_{m}^{\infty}\left\{1 X_{m} \cdot 1 w_{m}(\eta){ }_{2} X_{m} \cdot 2 w_{m}(1-\eta)\right\} \sin \mu_{m} \xi\right. \\
& +\sum_{n}^{\infty}\left\{\left\{_{1} Y_{n \cdot 1} w_{n}(\xi)+{ }_{2} Y_{n^{*} 2} w_{n}(1-\xi)\right\} \sin \mu_{n} \eta\right] \\
& { }_{1} \theta_{x}=\frac{a}{D}\left[\sum_{m}^{\infty}\left\{1 X_{m \cdot 1} \theta_{x m}(\eta)+{ }_{2} X_{m \cdot 2} \theta_{x m}(1-\eta)\right\} \cos \mu_{m} \xi\right. \\
& \left.+\sum_{n}^{\infty}\left\{{ }_{1} Y_{n \cdot 1} \theta_{x n}(\xi)+{ }_{2} Y_{n \cdot 2} \theta_{x n}(1-\xi)\right\} \sin \mu_{n} n\right] \\
& { }_{1} \theta_{y}=\frac{a}{D}\left[\sum_{m}^{\infty}\left\{{ }_{1} X_{m \cdot 1} \theta_{y m}(\eta)+{ }_{2} X_{m} \cdot{ }_{2} \theta_{y m}(1-\eta)\right\} \sin \mu_{m} \xi\right. \\
& \left.+\sum_{n}^{\infty}\left\{Y_{1} Y_{n \cdot 1} \theta_{y n}(\xi)+{ }_{2} Y_{n \cdot 2} \theta_{y n}(1-\xi)\right\} \cos \mu_{n} \eta\right]
\end{aligned}
$$

但し、単純支持板の場合 : $m, n=0,1,2,3, \cdots$

固定板の場合 $\quad: m, n=1,2,3, \cdots$

3.3) 未定係数の決定

集中質量を有する周辺単純支持平板と周辺固定平板の固有振動数 と固有振動モードは、未充足の境界条件、即ち

周辺単純支持板の場合：

$$
M_{x y}(0, \eta)=M_{x y}(1, \eta)=M_{x y}(\xi, 0)=M_{x y}(\xi, 1)=0
$$

周辺固定板の場合 :

$$
\theta_{x}(0, \eta)=\theta_{x}(1, \eta)=\theta_{y}(\xi, 0)=\theta_{y}(\xi, 1)=0
$$

と、平板と集中質量の接触条件

${ }_{M} w={ }_{0} w\left(\xi_{M}, \eta_{M}\right)+1 w\left(\xi_{M}, \eta_{M}\right)$

を用い、フーリェ正弦・余弦級数に展開して得られる下記の形の固 有方程式

$$
\left[\begin{array}{lllll}
K_{11} & K_{12} & K_{13} & K_{14} & K_{15} \\
K_{21} & K_{22} & K_{23} & K_{24} & K_{25} \\
K_{31} & K_{32} & K_{33} & K_{34} & K_{35} \\
K_{41} & K_{42} & K_{43} & K_{44} & K_{45} \\
K_{51} & K_{52} & K_{53} & K_{54} & K_{55}
\end{array}\right]\left\{\begin{array}{l}
{ }_{1} X_{m} \\
2 X_{m} \\
{ }_{1} Y_{n} \\
{ }_{2} Y_{n} \\
P
\end{array}\right\}=0
$$

を解くと求まる。 


\section{4) Rayleigh-Ritz法による固有振動解}

集中質量を有するMind I in平板の固有振動解析を行うに当たって、 本報告で提示した重站合せ法を用いた級数解法の精度を確認するた め、代数関数を使用したRayleigh-Ritz法による固有振動解を求め た。この場合、使用したエネルギー汎関数は

$$
\begin{aligned}
\Pi=\frac{1}{2} \iint[ & D\left\{\left(\frac{\partial \theta_{x}}{\partial x}+\frac{\partial \theta_{y}}{\partial y}\right)^{2}-2 \nu_{1}\left(\frac{\partial \theta_{x}}{\partial x} \frac{\partial \theta_{y}}{\partial y}-\frac{1}{4}\left(\frac{\partial \theta_{x}}{\partial y}+\frac{\partial \theta_{y}}{\partial x}\right)^{2}\right)\right\} \\
& +\kappa G h\left\{\left(\frac{\partial w}{\partial x}+\theta_{x}\right)^{2}+\left(\frac{\partial w}{\partial y}+\theta_{y}\right)^{2}\right\} \\
& \left.-\omega^{2} \rho h\left\{w^{2}+\frac{h^{2}}{12}\left(\theta_{x}^{2}+\theta_{y}^{2}\right)\right\}\right] d x d y \\
& -\frac{1}{2} \omega^{2} M \omega\left(x_{M}, y_{M}\right)^{2}
\end{aligned}
$$

で表され、多項式は既報告 ${ }^{8)}$ に倣い各変数共、55項を採用した。

\section{4．計算結果の比較と考察}

\section{1) 計算の概要}

数值計算は、ポアソン比を $\nu=0.2$ 、剪断補正係数を $\kappa=5 / 6$ とし て行い、固有振動数を下式で無次元化し、入の值で整理する。

$$
\omega=\frac{\lambda}{a^{2}} \sqrt{\frac{D}{\rho h}}
$$

また、集中質量を有する平板の振動性状を検討するために、変数と

して下記の量を設定した。

平板の辺長比 : $\phi=b / a=1.0,1.2,1.5,2.0$

平板の板厚比 : $h / a=0.010,0.025,0.050,0.075,0.100$

集中質量の比 : $k=M / a b h \rho=0.0,0.1,0.2,0.3, \cdots \cdots, 1.0$

また、集中質量の作用する位置を

$$
x_{M} / a=0.5,0.6,0.7,0.8,0.9 \quad y_{M} / b=0.5,0.6,0.7,0.8,0.9
$$

の範囲で移動させ、周辺単純支持と固定平板について、6 次迄の固 有振動数を求めた。尚、級数は各61項を採用した（付録を参照）。

4.2) 集中質量を有する周辺単純支持平板

表-1は、集中質量を伴った周辺単純支持平板の固有振動の内、基 本振動数（1 次固有振動数）の一部を掲げたものである[高次の固 有振動数については、紙面の都合上、割愛する】。提示した解法の 妥当性を検討するため、代数関数を使用したRayleigh一Ritz解との 比較を、集中質量が平板の中央点に作用する場合について行った。 図-2は、両解法から得られた結果を比較したもので、両者は、ほぼ 一致し、その差は最大でも1〜2\%程度であり、図上では差異を認め られない。基本振動数に及ぼす集中質量の影響は、平板の中央部に 集中質量が作用する場合、比較的小さな質量でも、急激な基本振動


図-2 周辺単純支持平板の基本振動数に及ぼす集中質量の影響（集中質量の作用位置 : 平板の中央点）

数の低下が見られ、集中質量の占める割合が增加するに従って低下 の度合いは鈍化する。当然のことながら、集中質量が支持辺の近傍 に作用する場合、基本振動数の低下する割合は、中央部に作用する 場合に比べて小さくなる。

基本振動数に及ぼす集中質量の影響は、S. Dunkerleyの式 ${ }^{10)}$ を利 用し、2 点間を補間すると、ほぼ推定することができる。これは、 集中質量を伴わない平板の基本固有振動数と、集中質量を伴った平
板の固有振動数から、集中質量単独による振動数を分離し、この值 を用いて、任意の集中質量に対する固有振動数を推定するものであ る。即ち集中質量単独による角振動数の推定は、Dunkerley式から

$$
\frac{1}{\omega^{2}}=\frac{1}{\omega_{0}^{2}}+\frac{1}{\omega^{2}}
$$

但し、 $\omega$ : 集中質量を伴った平板の角振動数 $\omega_{0}:$ 集中質量を伴わない平板の角振動数

表-1 集中質量を有する周辺単純支持平板の基本振動数 $\lambda$ （単位 : $\omega=\lambda \sqrt{D / \rho h} / a^{2}$ ）

\begin{tabular}{|c|c|c|c|c|c|c|c|c|c|c|c|c|c|c|c|c|c|}
\hline \multirow{3}{*}{$\frac{b}{a}$} & \multirow{3}{*}{$\frac{y_{M}}{b}$} & \multirow{3}{*}{$\frac{M}{a b h \rho}$} & \multicolumn{5}{|c|}{$h / a=0.01$} & \multicolumn{5}{|c|}{$h / a=0.05$} & \multicolumn{5}{|c|}{$h / a=0.10$} \\
\hline & & & \multicolumn{5}{|c|}{$x_{M} / a$} & \multicolumn{5}{|c|}{$x_{M} / a$} & \multicolumn{5}{|c|}{$x_{M} / a$} \\
\hline & & & 0.5 & 0.6 & 0.1 & 0.8 & 0.9 & 0,5 & 0.6 & 0.7 & 0.8 & 0.9 & 0.5 & 0.6 & 0.7 & 0.8 & 0.9 \\
\hline \multirow{6}{*}{1.0} & 0.5 & $\begin{array}{l}0.1 \\
0.5 \\
1.0 \\
\end{array}$ & $\begin{array}{r}16.51 \\
11.02 \\
8.435 \\
\end{array}$ & $\begin{array}{l}16.71 \\
11.27 \\
8.645 \\
\end{array}$ & $\begin{array}{r}17.32 \\
12.13 \\
9.382 \\
\end{array}$ & $\begin{array}{l}18.28 \\
14.01 \\
11.11 \\
\end{array}$ & $\begin{array}{l}19.24 \\
17.48 \\
15.32 \\
\end{array}$ & $\begin{array}{l}16.07 \\
10.70 \\
8.184 \\
\end{array}$ & $\begin{array}{c}16.26 \\
10.94 \\
8.382 \\
\end{array}$ & $\begin{array}{l}16.85 \\
11.76 \\
9.075\end{array}$ & $\begin{array}{l}17.77 \\
13.54 \\
10.69 \\
\end{array}$ & $\begin{array}{l}18.71 \\
16.90 \\
14.64\end{array}$ & $\begin{array}{c}15.35 \\
10.13 \\
7.706 \\
\end{array}$ & $\begin{array}{c}15.54 \\
10.34 \\
7.881 \\
\end{array}$ & \begin{tabular}{|l|}
16.09 \\
11.08 \\
8.487 \\
\end{tabular} & $\begin{array}{r}16.96 \\
12.68 \\
9.879 \\
\end{array}$ & $\begin{array}{l}17.87 \\
15.85 \\
13.28 \\
\end{array}$ \\
\hline & 0.6 & $\begin{array}{l}0.1 \\
0.5 \\
1.0\end{array}$ & $\begin{array}{c}16.71 \\
11.27 \\
8.645 \\
\end{array}$ & $\begin{array}{l}16.90 \\
11.52 \\
8.855\end{array}$ & $\begin{array}{r}17.49 \\
12.38 \\
9.592 \\
\end{array}$ & $\begin{array}{l}18.39 \\
14.24 \\
11.32 \\
\end{array}$ & $\begin{array}{l}19.28 \\
17.64 \\
15.53 \\
\end{array}$ & \begin{tabular}{|c|}
16.26 \\
10.94 \\
8.382 \\
\end{tabular} & $\begin{array}{c}16.45 \\
11.18 \\
8.579 \\
\end{array}$ & $\begin{array}{l}17.01 \\
11.99 \\
9.270\end{array}$ & $\begin{array}{l}17.88 \\
13.76 \\
10.88 \\
\end{array}$ & $\begin{array}{l}18.75 \\
17.05 \\
14.83 \\
\end{array}$ & $\begin{array}{c}15.54 \\
10.34 \\
7.881 \\
\end{array}$ & $\begin{array}{l}15.71 \\
10.52 \\
8.054 \\
\end{array}$ & \begin{tabular}{|l|}
16.24 \\
11.29 \\
8.656 \\
\end{tabular} & $\begin{array}{l}17.06 \\
12.87 \\
10.04\end{array}$ & $\begin{array}{l}17.91 \\
15.99 \\
13.44 \\
\end{array}$ \\
\hline & 0.7 & $\begin{array}{l}0.1 \\
0.5 \\
1.0\end{array}$ & $\begin{array}{l}17.32 \\
12.13 \\
9.382 \\
\end{array}$ & $\begin{array}{r}17.49 \\
12.38 \\
9.592 \\
\end{array}$ & $\begin{array}{l}17.98 \\
13.23 \\
10.33 \\
\end{array}$ & $\begin{array}{l}18.70 \\
15.03 \\
12.06 \\
\end{array}$ & $\begin{array}{l}19.37 \\
18.09 \\
16.20 \\
\end{array}$ & \begin{tabular}{|c|}
16.85 \\
11.76 \\
9.075 \\
\end{tabular} & $\begin{array}{l}17.01 \\
11.99 \\
9.270 \\
\end{array}$ & $\begin{array}{c}17.48 \\
12.79 \\
9.957 \\
\end{array}$ & $\begin{array}{l}18.18 \\
14.50 \\
11.56 \\
\end{array}$ & $\begin{array}{l}18.84 \\
17.50 \\
15.45\end{array}$ & $\begin{array}{l}16.09 \\
11.08 \\
8.487 \\
\end{array}$ & $\begin{array}{c}16.24 \\
11.29 \\
8.656 \\
\end{array}$ & $\begin{array}{l}16.68 \\
12.00 \\
9.244 \\
\end{array}$ & $\begin{array}{l}17.35 \\
13.53 \\
10.60 \\
\end{array}$ & $\begin{array}{l}18.00 \\
16.44 \\
13.95 \\
\end{array}$ \\
\hline & 0.8 & $\begin{array}{l}0.1 \\
0.5 \\
1.0\end{array}$ & $\begin{array}{l}18.28 \\
14.01 \\
11.11 \\
\end{array}$ & $\begin{array}{l}18.39 \\
14.24 \\
11.32 \\
\end{array}$ & $\begin{array}{l}18.70 \\
15.03 \\
12.06\end{array}$ & $\begin{array}{l}19.13 \\
16.60 \\
13.76 \\
\end{array}$ & $\begin{array}{l}19.50 \\
18.78 \\
17.47 \\
\end{array}$ & $\begin{array}{l}17.77 \\
13.54 \\
10.69 \\
\end{array}$ & $\begin{array}{l}17.88 \\
13.76 \\
10.88 \\
\end{array}$ & $\begin{array}{l}18.18 \\
14.50 \\
11.56 \\
\end{array}$ & $\begin{array}{r}18.60 \\
16.00 \\
13.12 \\
\end{array}$ & $\begin{array}{l}18.96 \\
18.19 \\
16.68\end{array}$ & $\begin{array}{c}16.96 \\
12.68 \\
9.879 \\
\end{array}$ & $\begin{array}{l}17.06 \\
12.87 \\
10.04 \\
\end{array}$ & $\begin{array}{l}17.35 \\
13.53 \\
10.60 \\
\end{array}$ & $\begin{array}{l}17.76 \\
14.91 \\
11.89 \\
\end{array}$ & $\begin{array}{l}18.12 \\
17.19 \\
15.03 \\
\end{array}$ \\
\hline & 0.9 & $\begin{array}{l}0.1 \\
0.5 \\
1.0\end{array}$ & $\begin{array}{l}19.24 \\
17.48 \\
15.32 \\
\end{array}$ & $\begin{array}{l}19.28 \\
17.64 \\
15.53 \\
\end{array}$ & $\begin{array}{l}19.37 \\
18.09 \\
16.20 \\
\end{array}$ & $\begin{array}{l}19.50 \\
18.78 \\
17.47 \\
\end{array}$ & $\begin{array}{l}19.60 \\
19.41 \\
19.08\end{array}$ & $\begin{array}{l}18.71 \\
16.90 \\
14.64 \\
\end{array}$ & $\begin{array}{l}18.75 \\
17.05 \\
14.83\end{array}$ & $\begin{array}{l}18.84 \\
17.50 \\
15.45 \\
\end{array}$ & $\begin{array}{l}18.96 \\
18.19 \\
16.68\end{array}$ & $\begin{array}{l}19.06 \\
18.87 \\
18.44\end{array}$ & $\begin{array}{l}17.87 \\
15.85 \\
13.28 \\
\end{array}$ & $\begin{array}{l}17.91 \\
15.99 \\
13.44\end{array}$ & $\begin{array}{l}18.00 \\
16.44 \\
13.95\end{array}$ & $\begin{array}{l}18.12 \\
17.19 \\
15.03\end{array}$ & $\begin{array}{l}18.22 \\
17.98 \\
17.13 \\
\end{array}$ \\
\hline & ref. & 0.0 & \multicolumn{5}{|c|}{19.63} & \multicolumn{5}{|c|}{19.10} & \multicolumn{5}{|c|}{18.26} \\
\hline \multirow{6}{*}{1.2} & 0.5 & $\begin{array}{l}0.1 \\
0.5 \\
1.0\end{array}$ & $\begin{array}{c}13.99 \\
9.325 \\
7.134 \\
\end{array}$ & $\begin{array}{c}14.15 \\
9.516 \\
7.290 \\
\end{array}$ & $\begin{array}{c}14.66 \\
10.18 \\
7.844 \\
\end{array}$ & $\begin{array}{c}15.47 \\
11.69 \\
9.185 \\
\end{array}$ & $\begin{array}{l}16.31 \\
14.70 \\
12.69\end{array}$ & $\begin{array}{c}13.66 \\
9.092 \\
6.949 \\
\end{array}$ & $\begin{array}{l}13.82 \\
9.274 \\
7.096 \\
\end{array}$ & $\begin{array}{r}14.31 \\
9.906 \\
7.619 \\
\end{array}$ & $\begin{array}{c}15.09 \\
11.34 \\
8.880\end{array}$ & $\begin{array}{l}15.91 \\
14.25 \\
12.18\end{array}$ & $\begin{array}{l}13.13 \\
8.663 \\
6.593 \\
\end{array}$ & $\begin{array}{l}13.28 \\
8.828 \\
6.723 \\
\end{array}$ & \begin{tabular}{|c|}
13.73 \\
9.399 \\
7.186 \\
\end{tabular} & $\begin{array}{c}14.48 \\
10.69 \\
8.289 \\
\end{array}$ & $\begin{array}{l}15.28 \\
13.44 \\
11.15 \\
\end{array}$ \\
\hline & 0.6 & $\begin{array}{l}0.1 \\
0.5 \\
1.0\end{array}$ & $\begin{array}{c}14.17 \\
9.554 \\
7.328 \\
\end{array}$ & $\begin{array}{r}14.32 \\
9.744 \\
7.484 \\
\end{array}$ & $\begin{array}{l}14.80 \\
10.41 \\
8.038\end{array}$ & $\begin{array}{l}15.57 \\
11.90 \\
9.379\end{array}$ & $\begin{array}{l}16.34 \\
14.84 \\
12.88 \\
\end{array}$ & $\begin{array}{r}13.84 \\
9.312 \\
7.133 \\
\end{array}$ & $\begin{array}{r}13.99 \\
9.492 \\
7.280 \\
\end{array}$ & $\begin{array}{l}14.45 \\
10.12 \\
7.802\end{array}$ & $\begin{array}{r}15.19 \\
11.54 \\
9.061\end{array}$ & $\begin{array}{l}15.94 \\
14.39 \\
12.35 \\
\end{array}$ & $\begin{array}{l}13.29 \\
8.864 \\
6.758 \\
\end{array}$ & $\begin{array}{r}13.43 \\
9.027 \\
6.888 \\
\end{array}$ & $\begin{array}{r}13.87 \\
9.595 \\
7.347 \\
\end{array}$ & $\begin{array}{r}14.57 \\
10.88 \\
8.444 \\
\end{array}$ & $\begin{array}{l}15.31 \\
13.58 \\
11.30 \\
\end{array}$ \\
\hline & 0.7 & $\begin{array}{l}0.1 \\
0.5 \\
1.0\end{array}$ & $\begin{array}{l}14.70 \\
10.33 \\
8.001 \\
\end{array}$ & $\begin{array}{r}14.83 \\
10.52 \\
8.157 \\
\end{array}$ & $\begin{array}{r}15.23 \\
11.17 \\
8.714 \\
\end{array}$ & $\begin{array}{l}15.84 \\
12.62 \\
10.06 \\
\end{array}$ & $\begin{array}{l}16.42 \\
15.26 \\
13.49 \\
\end{array}$ & $\begin{array}{c}14.35 \\
10.05 \\
7.772 \\
\end{array}$ & $\begin{array}{c}14.48 \\
10.23 \\
7.919 \\
\end{array}$ & $\begin{array}{c}14.86 \\
10.85 \\
8.438 \\
\end{array}$ & $\begin{array}{c}15.45 \\
12.22 \\
9.687 \\
\end{array}$ & $\begin{array}{l}16.02 \\
14.81 \\
12.92 \\
\end{array}$ & $\begin{array}{c}13.7 ? \\
9.541 \\
7.328\end{array}$ & $\begin{array}{c}13.90 \\
9.701 \\
7.455 \\
\end{array}$ & \begin{tabular}{|l|}
14.26 \\
10.26 \\
7.905 \\
\end{tabular} & $\begin{array}{l}14.83 \\
11.50 \\
8.979 \\
\end{array}$ & $\begin{array}{l}15.39 \\
14.00 \\
11.78 \\
\end{array}$ \\
\hline & 0.8 & $\begin{array}{l}0.1 \\
0.5 \\
1.0\end{array}$ & $\begin{array}{r}15.51 \\
11.98 \\
9.545 \\
\end{array}$ & $\begin{array}{c}15.60 \\
12.16 \\
9.707\end{array}$ & $\begin{array}{l}15.86 \\
12.78 \\
10.27 \\
\end{array}$ & $\begin{array}{l}16.21 \\
14.04 \\
11.60 \\
\end{array}$ & $\begin{array}{l}16.53 \\
15.89 \\
14.67 \\
\end{array}$ & $\begin{array}{r}15.13 \\
11.63 \\
9.232 \\
\end{array}$ & $\begin{array}{c}15.22 \\
11.80 \\
9.380 \\
\end{array}$ & $\begin{array}{r}15.47 \\
12.38 \\
9.900 \\
\end{array}$ & $\begin{array}{l}15.82 \\
13.59 \\
11.12 \\
\end{array}$ & $\begin{array}{l}16.13 \\
15.45 \\
14.06 \\
\end{array}$ & $\begin{array}{c}14.53 \\
10.98 \\
8.612 \\
\end{array}$ & $\begin{array}{l}14.61 \\
11.13 \\
8.737\end{array}$ & $\begin{array}{l}14.85 \\
11.66 \\
9.174\end{array}$ & $\begin{array}{l}15.19 \\
12.77 \\
10.20\end{array}$ & $\begin{array}{l}15.50 \\
14.68 \\
12.80 \\
\end{array}$ \\
\hline & 0.9 & $\begin{array}{l}0.1 \\
0.5 \\
1.0 \\
\end{array}$ & $\begin{array}{l}16.32 \\
14.89 \\
13.16 \\
\end{array}$ & $\begin{array}{l}16.35 \\
15.01 \\
13.32 \\
\end{array}$ & $\begin{array}{l}16.43 \\
15.37 \\
13.85 \\
\end{array}$ & $\begin{array}{r}16.53 \\
15.93 \\
14.85 \\
\end{array}$ & $\begin{array}{l}16.61 \\
16.46 \\
16.17 \\
\end{array}$ & $\begin{array}{l}15.92 \\
14.46 \\
12.66 \\
\end{array}$ & $\begin{array}{l}15.95 \\
14.58 \\
12.81 \\
\end{array}$ & $\begin{array}{l}16.03 \\
14.94 \\
13.30 \\
\end{array}$ & $\begin{array}{l}16.13 \\
15.49 \\
14.27 \\
\end{array}$ & $\begin{array}{l}16.22 \\
16.05 \\
15.69 \\
\end{array}$ & $\begin{array}{l}15.29 \\
13.69 \\
11.64 \\
\end{array}$ & $\begin{array}{l}15.32 \\
13.80 \\
11.77 \\
\end{array}$ & $\begin{array}{r}15.40 \\
14.16 \\
12.19 \\
\end{array}$ & $\begin{array}{l}15.50 \\
14.75 \\
13.06 \\
\end{array}$ & $\begin{array}{l}15.58 \\
15.38 \\
14.73 \\
\end{array}$ \\
\hline & ref. & 0.0 & \multicolumn{5}{|c|}{16.64} & \multicolumn{5}{|c|}{16.25} & \multicolumn{5}{|c|}{15.61} \\
\hline \multirow{6}{*}{1.5} & 0.5 & $\begin{array}{l}0.1 \\
0.5 \\
1.0\end{array}$ & $\begin{array}{l}11.92 \\
7.899 \\
6.028 \\
\end{array}$ & $\begin{array}{c}12.05 \\
8.030 \\
6.130 \\
\end{array}$ & $\begin{array}{c}12.46 \\
8.502 \\
6.505 \\
\end{array}$ & $\begin{array}{r}13.15 \\
9.644 \\
7.468 \\
\end{array}$ & $\begin{array}{l}13.90 \\
12.29 \\
10.29 \\
\end{array}$ & $\begin{array}{r}11.69 \\
7.737 \\
5.898 \\
\end{array}$ & $\begin{array}{l}11.82 \\
7.860 \\
5.994 \\
\end{array}$ & $\begin{array}{l}12.21 \\
8.307 \\
6.346 \\
\end{array}$ & $\begin{array}{c}12.88 \\
9.394 \\
7.254 \\
\end{array}$ & $\begin{array}{l}13.62 \\
11.96 \\
9.908\end{array}$ & $\begin{array}{r}11.31 \\
7.423 \\
5.638 \\
\end{array}$ & $\begin{array}{l}11.42 \\
7.534 \\
5.722 \\
\end{array}$ & \begin{tabular}{|c|}
11.80 \\
7.938 \\
6.033 \\
\end{tabular} & $\begin{array}{r}12.44 \\
8.923 \\
6.834 \\
\end{array}$ & $\begin{array}{l}13.17 \\
11.32 \\
9.148 \\
\end{array}$ \\
\hline & 0.6 & $\begin{array}{l}0.1 \\
0.5 \\
1.0 \\
\end{array}$ & $\begin{array}{r}12.07 \\
8.105 \\
6.203 \\
\end{array}$ & $\begin{array}{r}12.20 \\
8.236 \\
6.305 \\
\end{array}$ & $\begin{array}{r}12.59 \\
8.708 \\
6.681 \\
\end{array}$ & $\begin{array}{r}13.24 \\
9.844 \\
7.645 \\
\end{array}$ & $\begin{array}{l}13.93 \\
12.43 \\
10.46 \\
\end{array}$ & $\begin{array}{r}11.84 \\
7.935 \\
6.066 \\
\end{array}$ & $\begin{array}{r}11.96 \\
8.059 \\
6.161 \\
\end{array}$ & $\begin{array}{l}12.34 \\
8.505 \\
6.514 \\
\end{array}$ & $\begin{array}{r}12.97 \\
9.585 \\
7.420 \\
\end{array}$ & $\begin{array}{l}13.65 \\
12.09 \\
10.07\end{array}$ & $\begin{array}{l}11.45 \\
7.606 \\
5.790 \\
\end{array}$ & $\begin{array}{r}11.56 \\
7.718 \\
5.874 \\
\end{array}$ & \begin{tabular}{|r|}
11.92 \\
8.119 \\
6.184 \\
\end{tabular} & $\begin{array}{l}12.53 \\
9.097 \\
6.979\end{array}$ & $\begin{array}{c}13.20 \\
11.46 \\
9.282 \\
\end{array}$ \\
\hline & 0.7 & $\begin{array}{l}0.1 \\
0.5 \\
1.0 \\
\end{array}$ & $\begin{array}{c}12.54 \\
8.796 \\
6.805 \\
\end{array}$ & $\begin{array}{r}12.64 \\
8.929 \\
6.910\end{array}$ & $\begin{array}{r}12.97 \\
9.401 \\
7.290\end{array}$ & $\begin{array}{c}13.49 \\
10.51 \\
8.257 \\
\end{array}$ & $\begin{array}{l}14.01 \\
12.86 \\
11.04 \\
\end{array}$ & $\begin{array}{r}12.29 \\
8.601 \\
6.643 \\
\end{array}$ & $\begin{array}{l}12.40 \\
8.726 \\
6.739 \\
\end{array}$ & $\begin{aligned} 12.71 \\
9.171 \\
7.093\end{aligned}$ & $\begin{array}{l}13.22 \\
10.22 \\
7.996\end{array}$ & $\begin{array}{l}13.73 \\
12.51 \\
10.61\end{array}$ & $\begin{array}{l}11.88 \\
8.222 \\
6.311 \\
\end{array}$ & $\begin{array}{l}11.98 \\
8.333 \\
6.395 \\
\end{array}$ & \begin{tabular}{|l|}
12.28 \\
8.731 \\
6.701 \\
\end{tabular} & $\begin{array}{r}12.77 \\
9.681 \\
7.481 \\
\end{array}$ & $\begin{array}{l}13.27 \\
11.88 \\
9.736 \\
\end{array}$ \\
\hline & 0.8 & $\begin{array}{l}0.1 \\
0.5 \\
1.0 \\
\end{array}$ & $\begin{array}{c}13.24 \\
10.24 \\
8.173 \\
\end{array}$ & $\begin{array}{l}13.31 \\
10.38 \\
8.285 \\
\end{array}$ & $\begin{array}{r}13.52 \\
10.84 \\
8.684 \\
\end{array}$ & $\begin{array}{l}13.83 \\
11.84 \\
9.661\end{array}$ & $\begin{array}{l}14.10 \\
13.49 \\
12.21 \\
\end{array}$ & $\begin{array}{r}12.98 \\
9.995 \\
7.945 \\
\end{array}$ & $\begin{array}{c}13.05 \\
10.12 \\
8.047 \\
\end{array}$ & $\begin{array}{c}13.25 \\
10.56 \\
8.414\end{array}$ & $\begin{array}{r}13.55 \\
11.51 \\
9.313\end{array}$ & $\begin{array}{l}13.82 \\
13.17 \\
11.73\end{array}$ & $\begin{array}{r}12.54 \\
9.512 \\
7.475 \\
\end{array}$ & $\begin{array}{c}12.61 \\
9.624 \\
7.560\end{array}$ & $\begin{array}{l}12.81 \\
10.01 \\
7.867 \\
\end{array}$ & $\begin{array}{r}13 . \pm 0 \\
10.88 \\
8.621 \\
\end{array}$ & $\begin{array}{l}13.37 \\
12.58 \\
10.72 \\
\end{array}$ \\
\hline & 0.9 & $\begin{array}{l}0.1 \\
0.5 \\
1.0 \\
\end{array}$ & $\begin{array}{l}13.92 \\
12.73 \\
11.29 \\
\end{array}$ & $\begin{array}{l}13.95 \\
12.83 \\
11.42 \\
\end{array}$ & $\begin{array}{l}14.02 \\
13.12 \\
11.82 \\
\end{array}$ & $\begin{array}{l}14.10 \\
13.58 \\
12.63 \\
\end{array}$ & $\begin{array}{l}14.17 \\
14.04 \\
13.76 \\
\end{array}$ & $\begin{array}{l}3.65 \\
12.43 \\
10.93 \\
\end{array}$ & $\begin{array}{l}13.67 \\
12.52 \\
11.04\end{array}$ & $\begin{array}{l}13.74 \\
12.81 \\
11.43\end{array}$ & $\begin{array}{l}13.82 \\
13.27 \\
12.20\end{array}$ & $\begin{array}{l}13.90 \\
13.75 \\
13.41 \\
\end{array}$ & $\begin{array}{l}13.20 \\
11.87 \\
10.17\end{array}$ & $\begin{array}{l}13.22 \\
11.96 \\
10.26 \\
\end{array}$ & $\begin{array}{l}13.29 \\
12.24 \\
10.59 \\
\end{array}$ & $\begin{array}{l}13.37 \\
12.72 \\
11.28\end{array}$ & $\begin{array}{l}13.44 \\
13.27 \\
12.65\end{array}$ \\
\hline & ref. & 0.0 & \multicolumn{5}{|c|}{14,20} & \multicolumn{5}{|c|}{13.92} & \multicolumn{5}{|c|}{13.47} \\
\hline \multirow{6}{*}{2.0} & 0.5 & $\begin{array}{l}0.1 \\
0.5 \\
1.0 \\
\end{array}$ & $\begin{array}{l}10.28 \\
6.704 \\
5.082 \\
\end{array}$ & $\begin{array}{c}10.37 \\
6.773 \\
5.131 \\
\end{array}$ & $\begin{array}{r}10.69 \\
7.042 \\
5.327\end{array}$ & $\begin{array}{l}11.29 \\
7.786 \\
5.904 \\
\end{array}$ & $\begin{array}{l}12.02 \\
10.04 \\
7.928 \\
\end{array}$ & $\begin{array}{c}10.14 \\
6.596 \\
4.996 \\
\end{array}$ & $\begin{array}{l}10.23 \\
6.660 \\
5.040 \\
\end{array}$ & $\begin{array}{c}10.53 \\
6.911 \\
5.220 \\
\end{array}$ & $\begin{array}{r}11.11 \\
7.614 \\
5.761 \\
\end{array}$ & $\begin{array}{l}11.84 \\
9.772 \\
7.666 \\
\end{array}$ & $\begin{array}{l}9.870 \\
6.369 \\
4.806 \\
\end{array}$ & $\begin{array}{l}9.953 \\
6.425 \\
4.843 \\
\end{array}$ & $\begin{array}{c}10.24 \\
6.645 \\
4.999 \\
\end{array}$ & $\begin{array}{r}10.80 \\
7.276 \\
5.474 \\
\end{array}$ & $\begin{array}{l}11.52 \\
9.253 \\
7.137 \\
\end{array}$ \\
\hline & 0.6 & $\begin{array}{l}0.1 \\
0.5 \\
1.0 \\
\end{array}$ & $\begin{array}{r}10.42 \\
6.887 \\
5.236 \\
\end{array}$ & $\begin{array}{r}10.51 \\
6.957 \\
5.285 \\
\end{array}$ & $\begin{array}{c}10.81 \\
7.229 \\
5.483 \\
\end{array}$ & $\begin{array}{l}11.38 \\
7.974 \\
6.061\end{array}$ & $\begin{array}{c}12.05 \\
10.19 \\
8.087 \\
\end{array}$ & $\begin{array}{c}10.27 \\
6.774 \\
5.144 \\
\end{array}$ & $\begin{array}{c}10.36 \\
6.839 \\
5.189 \\
\end{array}$ & $\begin{array}{r}10.65 \\
7.091 \\
5.370\end{array}$ & $\begin{array}{r}11.20 \\
7.794 \\
5.910 \\
\end{array}$ & $\begin{array}{r}11.87 \\
9.927 \\
? .813 \\
\end{array}$ & $\begin{array}{l}10.00 \\
6.535 \\
4.942 \\
\end{array}$ & $\begin{array}{r}10.08 \\
6.591 \\
4.980 \\
\end{array}$ & \begin{tabular}{|l}
10.36 \\
6.813 \\
5.135 \\
\end{tabular} & $\begin{array}{l}10.89 \\
7.441 \\
5.607\end{array}$ & $\begin{array}{c}11.55 \\
9.397 \\
7.261 \\
\end{array}$ \\
\hline & 0.7 & $\begin{array}{l}0.1 \\
0.5 \\
1.0 \\
\end{array}$ & $\begin{array}{l}10.84 \\
7.503 \\
5.767 \\
\end{array}$ & $\begin{array}{c}10.92 \\
7.577 \\
5.819 \\
\end{array}$ & $\begin{array}{r}11.18 \\
7.859 \\
6.023 \\
\end{array}$ & $\begin{array}{c}11.63 \\
8.608 \\
6.610 \\
\end{array}$ & $\begin{array}{c}12.12 \\
10.69 \\
8.634 \\
\end{array}$ & $\begin{array}{c}10.68 \\
7.371 \\
5.655 \\
\end{array}$ & $\begin{array}{c}10.76 \\
7.439 \\
5.701 \\
\end{array}$ & $\begin{array}{l}11.01 \\
7.701 \\
5.888 \\
\end{array}$ & $\begin{array}{c}11.46 \\
8.404 \\
6.431 \\
\end{array}$ & $\begin{array}{l}11.94 \\
10.42 \\
8.319\end{array}$ & $\begin{array}{c}10.39 \\
7.091 \\
5.408 \\
\end{array}$ & $\begin{array}{r}10.47 \\
7.149 \\
5.446 \\
\end{array}$ & \begin{tabular}{|c|}
10.71 \\
7.377 \\
5.603 \\
\end{tabular} & $\begin{array}{l}11.14 \\
8.001 \\
6.070 \\
\end{array}$ & $\begin{array}{c}11.63 \\
9.867 \\
7.688 \\
\end{array}$ \\
\hline & 0.8 & $\begin{array}{l}0.1 \\
0.5 \\
1.0 \\
\end{array}$ & $\begin{array}{c}11.46 \\
8.792 \\
6.972 \\
\end{array}$ & $\begin{array}{c}11.52 \\
8.876 \\
7.031 \\
\end{array}$ & $\begin{array}{c}11.70 \\
9.180 \\
7.260\end{array}$ & $\begin{array}{r}11.96 \\
9.914 \\
7.880\end{array}$ & $\begin{array}{r}12.21 \\
11.50 \\
9.858 \\
\end{array}$ & $\begin{array}{l}11.29 \\
8.621 \\
6.809 \\
\end{array}$ & $\begin{array}{l}11.35 \\
8.698 \\
6.862 \\
\end{array}$ & $\begin{array}{r}11.52 \\
8.980 \\
7.068 \\
\end{array}$ & $\begin{array}{c}11.78 \\
9.672 \\
7.633 \\
\end{array}$ & $\begin{array}{l}12.03 \\
11.25 \\
9.465 \\
\end{array}$ & $\begin{array}{r}10.99 \\
8.257 \\
6.448 \\
\end{array}$ & $\begin{array}{l}11.05 \\
8.324 \\
6.490 \\
\end{array}$ & $\begin{array}{c}11.21 \\
8.568 \\
6.657 \\
\end{array}$ & $\begin{array}{r}11.47 \\
9.183 \\
7.124 \\
\end{array}$ & $\begin{array}{c}11.72 \\
10.74 \\
8.659 \\
\end{array}$ \\
\hline & 0.9 & $\begin{array}{l}0.1 \\
0.5 \\
1.0\end{array}$ & $\begin{array}{c}12.06 \\
11.01 \\
9.734 \\
\end{array}$ & $\begin{array}{c}12.08 \\
11.09 \\
9.817\end{array}$ & $\begin{array}{l}12.14 \\
11.32 \\
10.11 \\
\end{array}$ & $\begin{array}{l}12.22 \\
11.72 \\
10.74\end{array}$ & $\begin{array}{l}12.28 \\
12.15 \\
11.84\end{array}$ & $\begin{array}{r}11.89 \\
10.81 \\
9.470 \\
\end{array}$ & $\begin{array}{c}11.91 \\
10.88 \\
9.546 \\
\end{array}$ & $\begin{array}{c}11.97 \\
11.11 \\
9.810 \\
\end{array}$ & $\begin{array}{l}12.04 \\
11.51 \\
10.41 \\
\end{array}$ & $\begin{array}{l}12.10 \\
11.96 \\
11.56 \\
\end{array}$ & $\begin{array}{l}11.58 \\
10.39 \\
8.870 \\
\end{array}$ & $\begin{array}{l}11.60 \\
10.46 \\
8.931 \\
\end{array}$ & $\begin{array}{c}11.66 \\
10.68 \\
9.144 \\
\end{array}$ & $\begin{array}{r}11.73 \\
11.10 \\
9.647 \\
\end{array}$ & $\begin{array}{l}11.79 \\
11.62 \\
10.86\end{array}$ \\
\hline & ref. & 0.0 & \multicolumn{5}{|c|}{12.31} & \multicolumn{5}{|c|}{12.13} & \multicolumn{5}{|c|}{11.82} \\
\hline
\end{tabular}






$\lambda=8.438$



$\lambda=24.13$



$\lambda=40.49$



$\lambda=55.16$



$\lambda=68.50$



$\lambda=87.88$

図-4 集中質量を有する周辺単純支持平板の振動モード $\left(b / a=1.2, h / a=0.05, M / a b h \rho=1.0, x_{M} / a=0.7, y_{M} / b=0.7\right)$

$\omega_{P}:$ 集中質量単独による平板の角振動数

今、 $\omega, \omega_{0}$ は(14) 式で固有振動数を無次元化し、 $\omega_{P}$ を

$\omega_{P}=\frac{\lambda_{P}}{a} \sqrt{\frac{b}{a}} \sqrt{\frac{D}{M}}$

で無次元化すると、(15)式から次式が得られる。

$$
\frac{1}{\lambda^{2}}=\frac{1}{\lambda^{2}}+\frac{k}{\lambda^{2}}
$$

但し、 $k=M / a b h \rho:$ 集中質量と平板質量の比

上式は、集中質量による影響を近似表示することができる。図-3は、
平板の全質量に対する集中質量の比が $k=1.0$ の値で $\lambda_{P}$ の値を推定 し、 $\lambda_{0}, \lambda_{P}, k$ から補間した値と級数解の比較を行ったもので、中間 の值は最大誤差 $5 \%$ 程度の範囲で補間できることが分かる。微小な 集中質量に関しては、表-1に掲げた $k=0.1 や k=0.5$ から算出し た $\lambda_{P}$ の值を求めて補間すると、誤差の少ない形で基本振動数を推定 できる。図-4は、平板の辺長比 $b / a=1.2$ 、板厚比 $h / a=0.05$ 、質 量比 $k(=M / a b h \rho)=1.0$ 、作用位置 $x_{M} / a=0.7, y_{M} / b=0.7$ の場 合について、6 次迄の固有振動モードを、この種平板の振動モード の一例として揭げたものである。




図-5 周辺固定平板の基本振動数に及ぼす集中質量の影響（集中質量の作用位置 : 平板の中央点）








\section{3)集中質量を有する周辺固定平板.}

表-2は心、集中質量を伴った周辺固定平板の内、基本振動数の一部 を揭げたものである[高次の固有振動数は、紙面の都合上、割愛す る]。提示した本方法の妥当性を検討するため、Rayleigh一Ritz解 との比較を集中質量が平板の中央点に作用する場合について行い 比較の結果を図一5に掲げた。この場合、平板が細長く、且つ平板の 板厚比 $h / a$ の值が大きくなると、両者の間に相違を生ずる傾向にあ
るっこのような現象は、静的問題を扱った場合 11 ，12) にも見受けら れ、Rayleigh-Ritz法は、正方形板に比べて細長い長方形板では収 束性が若千劣るようで、図からも容易に読み取れる。

基本振動数に及ぼす集中質量の影響は、平板の中央部に集中質量 が位置する場合、比較的小さな質量でも、基本振動数の急激な低下 が見られ、平板自重等、平板の全面に分布する質量に比べて集中質 量の占める割合が増加するに伴って振動数の低下現象は鈍化する。

表-2 集中質量を有する周辺固定平板の基本振動数 $\lambda$ （単位： $\omega=\lambda \sqrt{D / \rho h} / a^{2}$ ）

\begin{tabular}{|c|c|c|c|c|c|c|c|c|c|c|c|c|c|c|c|c|c|}
\hline \multirow{3}{*}{$\frac{b}{a}$} & \multirow{3}{*}{$\frac{y_{M}}{b}$} & \multirow{3}{*}{$\frac{M}{a b h \rho}$} & \multicolumn{5}{|c|}{$h / a=0.01$} & \multicolumn{5}{|c|}{$h / a=0.05$} & \multicolumn{5}{|c|}{$h / a=0.10$} \\
\hline & & & \multicolumn{5}{|c|}{$x_{M} / a$} & \multicolumn{5}{|c|}{$x_{M} / a$} & \multicolumn{5}{|c|}{$x_{M} / a$} \\
\hline & & & 0.5 & 0.6 & 0.7 & 0.8 & 0.9 & 0.5 & 0.6 & 0.7 & 0,8 & 0.9 & 0.5 & 0.6 & 0.7 & 0.8 & 0.9 \\
\hline \multirow{6}{*}{1.0} & 0.5 & $\begin{array}{l}0.1 \\
0.5 \\
1.0\end{array}$ & $\begin{array}{l}27.94 \\
16.93 \\
12.61 \\
\end{array}$ & $\begin{array}{l}28.61 \\
17.52 \\
13.06\end{array}$ & $\begin{array}{l}30.69 \\
19.64 \\
14.71\end{array}$ & $\begin{array}{l}33.82 \\
24.83 \\
18.97 \\
\end{array}$ & $\begin{array}{l}35.74 \\
34.42 \\
31.18 \\
\end{array}$ & $\begin{array}{l}27.25 \\
16.38 \\
12.16 \\
\end{array}$ & $\begin{array}{l}27.88 \\
16.92 \\
12.57 \\
\end{array}$ & $\begin{array}{l}29.87 \\
18.84 \\
14.04 \\
\end{array}$ & $\begin{array}{l}32.90 \\
23.43 \\
17.68 \\
\end{array}$ & $\begin{array}{l}34.86 \\
32.89 \\
27.60 \\
\end{array}$ & $\begin{array}{l}25.43 \\
14.97 \\
11.04\end{array}$ & $\begin{array}{l}25.98 \\
15.39 \\
11.35 \\
\end{array}$ & $\begin{array}{l}27.72 \\
16.85 \\
12.43 \\
\end{array}$ & $\begin{array}{l}30.51 \\
20.16 \\
14.88 \\
\end{array}$ & $\begin{array}{l}32.57 \\
27.48 \\
20.43 \\
\end{array}$ \\
\hline & 0.6 & $\begin{array}{l}0.1 \\
0.5 \\
1.0\end{array}$ & $\begin{array}{r}28.61 \\
17.52 \\
.13 .06 \\
\end{array}$ & $\begin{array}{l}29.25 \\
18.10 \\
13.50\end{array}$ & $\begin{array}{l}31.23 \\
20.20 \\
15.14\end{array}$ & $\begin{array}{l}34.10 \\
25.35 \\
19.35\end{array}$ & \begin{tabular}{|l|}
35.77 \\
34.63 \\
31.56 \\
\end{tabular} & $\begin{array}{l}27.88 \\
16.92 \\
12.57 \\
\end{array}$ & $\begin{array}{l}28.49 \\
17.45 \\
12.97\end{array}$ & $\begin{array}{l}30.39 \\
19.34 \\
14.41 \\
\end{array}$ & $\begin{array}{l}33.19 \\
23.89 \\
18.00 \\
\end{array}$ & $\begin{array}{l}34.90 \\
33.15 \\
27.87 \\
\end{array}$ & $\begin{array}{l}25.98 \\
15.39 \\
11.35\end{array}$ & $\begin{array}{l}26.52 \\
15.80 \\
11.65\end{array}$ & $\begin{array}{l}28.19 \\
17.23 \\
12.70 \\
\end{array}$ & $\begin{array}{l}30.80 \\
20.47 \\
15.09 \\
\end{array}$ & $\begin{array}{l}32.62 \\
27.72 \\
20.53 \\
\end{array}$ \\
\hline & 0.7 & $\begin{array}{l}0.1 \\
0.5 \\
1.0 \\
\end{array}$ & $\begin{array}{l}30.69 . \\
19.64 \\
14.71\end{array}$ & $\begin{array}{l}31.23 \\
20.20 \\
15.14 \\
\end{array}$ & $\begin{array}{l}32.81 \\
22.23 \\
16.69 \\
\end{array}$ & $\begin{array}{l}34.84 \\
27.22 \\
20.77 \\
\end{array}$ & \begin{tabular}{|l|}
35.85 \\
35.17 \\
32.78 \\
\end{tabular} & $\begin{array}{l}29.87 \\
18.84 \\
14.04 \\
\end{array}$ & $\begin{array}{l}30.39 \\
19.34 \\
14.41\end{array}$ & $\begin{array}{l}31.92 \\
21.14 \\
15.76 \\
\end{array}$ & $\begin{array}{l}33.93 \\
25.51 \\
19.16 \\
\end{array}$ & $\begin{array}{l}34.98 \\
33.89 \\
28.79 \\
\end{array}$ & $\begin{array}{l}27.72 \\
16.85 \\
12.43 \\
\end{array}$ & $\begin{array}{l}28.19 \\
17.23 \\
12.70 \\
\end{array}$ & $\begin{array}{l}29.59 \\
18.55 \\
13.64 \\
\end{array}$ & $\begin{array}{l}31.56 \\
21.56 \\
15.81 \\
\end{array}$ & $\begin{array}{l}32.72 \\
28.46 \\
20.89 \\
\end{array}$ \\
\hline & 0.8 & $\begin{array}{l}0.1 \\
0.5 \\
1.0\end{array}$ & $\begin{array}{l}33.82 \\
24.83 \\
18.97 \\
\end{array}$ & $\begin{array}{l}34.10 \\
25.35 \\
19.35 \\
\end{array}$ & $\begin{array}{l}34.84 \\
27.22 \\
20.77 \\
\end{array}$ & $\begin{array}{l}35.59 \\
31.50 \\
24.50 \\
\end{array}$ & $\begin{array}{l}35.92 \\
35.72 \\
34.83 \\
\end{array}$ & $\begin{array}{l}32.90 \\
23.43 \\
17.68 \\
\end{array}$ & $\begin{array}{l}33.19 \\
23.89 \\
18.00 \\
\end{array}$ & $\begin{array}{r}33.93 \\
25.51 \\
19.16 \\
\end{array}$ & $\begin{array}{l}34.71 \\
29.32 \\
22.09 \\
\end{array}$ & $\begin{array}{l}35.06 \\
34.73 \\
30.80 \\
\end{array}$ & $\begin{array}{l}30.51 \\
20.16 \\
14.88 \\
\end{array}$ & $\begin{array}{l}30.80 \\
20.47 \\
15.09 \\
\end{array}$ & $\begin{array}{l}31.56 \\
21.56 \\
15.81 \\
\end{array}$ & $\begin{array}{l}32.42 \\
24.04 \\
17.50\end{array}$ & $\begin{array}{l}32.82 \\
29.94 \\
21.70 \\
\end{array}$ \\
\hline & 0.9 & $\begin{array}{l}0.1 \\
0.5 \\
1.0\end{array}$ & $\begin{array}{l}35.74 \\
34.42 \\
31.18 \\
\end{array}$ & $\begin{array}{l}35.77 \\
34.63 \\
31.56 \\
\end{array}$ & $\begin{array}{l}35.85 \\
35.17 \\
32.78 \\
\end{array}$ & $\begin{array}{l}35.92 \\
35.72 \\
34.83 \\
\end{array}$ & \begin{tabular}{|}
35.95 \\
35.93 \\
35.91 \\
\end{tabular} & $\begin{array}{l}34.86 \\
32.89 \\
27.60 \\
\end{array}$ & $\begin{array}{l}34.90 \\
33.15 \\
27.87 \\
\end{array}$ & $\begin{array}{l}34.98 \\
33.89 \\
28.79 \\
\end{array}$ & $\begin{array}{l}35.06 \\
34.73 \\
30.80 \\
\end{array}$ & $\begin{array}{l}35.09 \\
35.07 \\
34.91 \\
\end{array}$ & $\begin{array}{l}32.57 \\
27.48 \\
20.43 \\
\end{array}$ & $\begin{array}{l}32.62 \\
27.72 \\
20.53 \\
\end{array}$ & $\begin{array}{l}32.72 \\
28.46 \\
20.89 \\
\end{array}$ & $\begin{array}{l}32.82 \\
29.94 \\
21.70 \\
\end{array}$ & $\begin{array}{l}32.86 \\
32.68 \\
24.02\end{array}$ \\
\hline & ref. & 0.0 & \multicolumn{5}{|c|}{35.95} & \multicolumn{5}{|c|}{35.09} & \multicolumn{5}{|c|}{32.87} \\
\hline \multirow{6}{*}{1.2} & 0.5 & $\begin{array}{l}0.1 \\
0.5 \\
1.0\end{array}$ & $\begin{array}{l}23.86 \\
14.42 \\
10.73\end{array}$ & $\begin{array}{l}24.37 \\
14.82 \\
11.03\end{array}$ & $\begin{array}{l}26.02 \\
16.33 \\
12.17\end{array}$ & $\begin{array}{l}28.73 \\
20.25 \\
15.28\end{array}$ & $\begin{array}{l}30.53 \\
29.08 \\
25.27\end{array}$ & $\begin{array}{l}23.35 \\
14.01 \\
10.40\end{array}$ & $\begin{array}{l}23.83 \\
14.38 \\
10.67\end{array}$ & $\begin{array}{l}25.41 \\
15.76 \\
11.71 \\
\end{array}$ & $\begin{array}{l}28.05 \\
19.29 \\
14.44 \\
\end{array}$ & $\begin{array}{l}29.88 \\
27.79 \\
22.83 \\
\end{array}$ & $\begin{array}{c}21.97 \\
12.93 \\
9.539 \\
\end{array}$ & $\begin{array}{c}22.40 \\
13.23 \\
9.757 \\
\end{array}$ & $\begin{array}{l}23.81 \\
14.33 \\
10.55 \\
\end{array}$ & $\begin{array}{l}26.25 \\
16.98 \\
12.51 \\
\end{array}$ & $\begin{array}{l}28.15 \\
23.48 \\
17.41\end{array}$ \\
\hline & 0.6 & $\begin{array}{l}0.1 \\
0.5 \\
1.0 \\
\end{array}$ & $\begin{array}{l}24.47 \\
14.99 \\
11.17 \\
\end{array}$ & $\begin{array}{l}24.96 \\
15.39 \\
11.47\end{array}$ & $\begin{array}{l}26.53 \\
16.89 \\
12.59\end{array}$ & $\begin{array}{l}29.01 \\
20.75 \\
15.65\end{array}$ & $\begin{array}{l}30.56 \\
29.31 \\
25.63 \\
\end{array}$ & $\begin{array}{l}23.93 \\
14.54 \\
10.80 \\
\end{array}$ & $\begin{array}{l}24.40 \\
14.90 \\
11.04\end{array}$ & $\begin{array}{l}25.91 \\
16.26 \\
12.08 \\
\end{array}$ & $\begin{array}{l}28.33 \\
19.74 \\
14.76 \\
\end{array}$ & $\begin{array}{l}29.92 \\
28.09 \\
22.89\end{array}$ & $\begin{array}{c}22.48 \\
13.35 \\
9.854 \\
\end{array}$ & $\begin{array}{l}22.90 \\
13.65 \\
10.07\end{array}$ & $\begin{array}{l}24.25 \\
14.71 \\
10.84\end{array}$ & $\begin{array}{l}26.53 \\
17.30 \\
12.73 \\
\end{array}$ & $\begin{array}{l}28.19 \\
23.71 \\
17.53\end{array}$ \\
\hline & 0.7 & $\begin{array}{l}0.1 \\
0.5 \\
1.0\end{array}$ & $\begin{array}{l}26.34 \\
17.00 \\
12.76\end{array}$ & $\begin{array}{l}26.75 \\
17.39 \\
13.04 \\
\end{array}$ & $\begin{array}{l}28.00 \\
18.82 \\
14.10 \\
\end{array}$ & $\begin{array}{l}29.72 \\
22.55 \\
17.03 \\
\end{array}$ & $\begin{array}{l}30.64 \\
29.91 \\
26.83 \\
\end{array}$ & $\begin{array}{l}25.72 \\
16.38 \\
12.23 \\
\end{array}$ & $\begin{array}{l}26.12 \\
16.73 \\
12.48 \\
\end{array}$ & $\begin{array}{l}27.34 \\
18.02 \\
13.42 \\
\end{array}$ & $\begin{array}{l}29.05 \\
21.33 \\
15.93 \\
\end{array}$ & $\begin{array}{l}30.00 \\
28.85 \\
23.77 \\
\end{array}$ & $\begin{array}{l}24.07 \\
14.80 \\
10.94\end{array}$ & $\begin{array}{l}24.44 \\
15.07 \\
11.13 \\
\end{array}$ & $\begin{array}{l}25.57 \\
16.05 \\
11.81 \\
\end{array}$ & $\begin{array}{l}27.25 \\
18.43 \\
13.51 \\
\end{array}$ & $\begin{array}{l}28.29 \\
24.46 \\
17.94 \\
\end{array}$ \\
\hline & 0.8 & $\begin{array}{l}0.1 \\
0.5 \\
1.0\end{array}$ & $\begin{array}{l}29.00 \\
21.74 \\
16.73\end{array}$ & $\begin{array}{l}29.22 \\
22.12 \\
16.99\end{array}$ & $\begin{array}{l}29.79 \\
23.47 \\
17.98\end{array}$ & $\begin{array}{l}30.42 \\
26.69 \\
20.64 \\
\end{array}$ & $\begin{array}{l}30.70 \\
30.50 \\
29.23 \\
\end{array}$ & $\begin{array}{l}28.32 \\
20.64 \\
15.68 \\
\end{array}$ & $\begin{array}{l}28.54 \\
20.97 \\
15.90 \\
\end{array}$ & $\begin{array}{l}29.12 \\
22.16 \\
16.72 \\
\end{array}$ & $\begin{array}{l}29.77 \\
25.05 \\
18.87 \\
\end{array}$ & $\begin{array}{l}30.06 \\
29.75 \\
25.80 \\
\end{array}$ & $\begin{array}{l}26.50 \\
17.98 \\
13.34 \\
\end{array}$ & $\begin{array}{l}26.72 \\
18.21 \\
13.48 \\
\end{array}$ & $\begin{array}{l}27.33 \\
19.03 \\
14.01\end{array}$ & $\begin{array}{l}28.03 \\
20.99 \\
15.31 \\
\end{array}$ & $\begin{array}{l}28.37 \\
26.02 \\
18.89\end{array}$ \\
\hline & 0.8 & $\begin{array}{l}0.1 \\
0.5 \\
1.0 \\
\end{array}$ & $\begin{array}{l}30.56 \\
29.58 \\
27.30\end{array}$ & $\begin{array}{l}30.59 \\
29.73 \\
25.59\end{array}$ & $\begin{array}{l}30.64 \\
30.13 \\
28.48\end{array}$ & $\begin{array}{l}30.70 \\
30.54 \\
29.90 \\
\end{array}$ & $\begin{array}{l}30.72 \\
30.71 \\
30.69 \\
\end{array}$ & $\begin{array}{l}29.91 \\
28.52 \\
24.69 \\
\end{array}$ & $\begin{array}{l}29.94 \\
28.71 \\
24.92\end{array}$ & $\begin{array}{l}30.00 \\
29.23 \\
25.66\end{array}$ & $\begin{array}{l}30.07 \\
29.82 \\
27.27 \\
\end{array}$ & $\begin{array}{l}30.09 \\
30.08 \\
29.97\end{array}$ & $\begin{array}{l}28.17 \\
24.68 \\
18.65 \\
\end{array}$ & $\begin{array}{l}28.21 \\
24.88 \\
18.74 \\
\end{array}$ & $\begin{array}{l}28.29 \\
25.51 \\
19.01\end{array}$ & $\begin{array}{l}28.37 \\
26.73 \\
19.64 \\
\end{array}$ & $\begin{array}{l}28.40 \\
28.32 \\
21.50 \\
\end{array}$ \\
\hline & ref. & 0.0 & \multicolumn{5}{|c|}{30.73} & \multicolumn{5}{|c|}{30.09} & \multicolumn{5}{|c|}{28,41} \\
\hline \multirow{6}{*}{1.5} & 0.5 & $\begin{array}{l}0.1 \\
0.5 \\
1.0 \\
\end{array}$ & $\begin{array}{r}20.86 \\
12.47 \\
9.242 \\
\end{array}$ & $\begin{array}{l}21.21 \\
12.68 \\
9.392 \\
\end{array}$ & $\begin{array}{l}22.42 \\
13.56 \\
10.03 \\
\end{array}$ & $\begin{array}{l}24.85 \\
16.19 \\
12.02 \\
\end{array}$ & $\begin{array}{l}26.78 \\
24.46 \\
19.50 \\
\end{array}$ & $\begin{array}{c}20.45 \\
12.14 \\
8.980 \\
\end{array}$ & $\begin{array}{c}20.78 \\
12.34 \\
9.119 \\
\end{array}$ & $\begin{array}{r}21.95 \\
13.15 \\
.9 .706 \\
\end{array}$ & $\begin{array}{r}24.31 \\
15.55 \\
11.49 \\
\end{array}$ & $\begin{array}{l}26.27 \\
23.11 \\
17.73 \\
\end{array}$ & $\begin{array}{c}19.33 \\
11.27 \\
8.290 \\
\end{array}$ & $\begin{array}{l}19.62 \\
11.43 \\
8.403 \\
\end{array}$ & $\begin{array}{c}20.68 \\
12.09 \\
8.872 \\
\end{array}$ & $\begin{array}{l}22.85 \\
13.96 \\
10.22 \\
\end{array}$ & $\begin{array}{l}24.88 \\
19.42 \\
14.24\end{array}$ \\
\hline & 0.6 & $\begin{array}{l}0.1 \\
0.5 \\
1.0\end{array}$ & $\begin{array}{c}21.43 \\
13.00 \\
9.653 \\
\end{array}$ & $\begin{array}{c}21.77 \\
13.21 \\
9.801 \\
\end{array}$ & $\begin{array}{l}22.94 \\
14.07 \\
10.43\end{array}$ & $\begin{array}{l}25.16 \\
16.67 \\
12.38 \\
\end{array}$ & $\begin{array}{l}26.82 \\
24.79 \\
19.81 \\
\end{array}$ & $\begin{array}{c}21.00 \\
12.63 \\
9.359 \\
\end{array}$ & $\begin{array}{l}21.32 \\
12.83 \\
9.495 \\
\end{array}$ & $\begin{array}{l}22.45 \\
13.63 \\
10.07 \\
\end{array}$ & $\begin{array}{l}24.63 \\
15.99 \\
11.81 \\
\end{array}$ & $\begin{array}{l}26.31 \\
23.44 \\
17.97 \\
\end{array}$ & $\begin{array}{c}19.82 \\
11.67 \\
8.591 \\
\end{array}$ & \begin{tabular}{|c|}
20.11 \\
11.83 \\
8.700 \\
\end{tabular} & $\begin{array}{r}21.12 \\
12.47 \\
9.152 \\
\end{array}$ & $\begin{array}{l}23.16 \\
14.29 \\
10.45 \\
\end{array}$ & $\begin{array}{l}24.92 \\
19.64 \\
14.37 \\
\end{array}$ \\
\hline & 0.7 & $\begin{array}{l}0.1 \\
0.5 \\
1.0\end{array}$ & $\begin{array}{l}23.15 \\
14.86 \\
11.12 \\
\end{array}$ & $\begin{array}{l}23.44 \\
15.07 \\
11.27\end{array}$ & $\begin{array}{l}24.41 \\
15.92 \\
11.86\end{array}$ & $\begin{array}{l}25.96 \\
18.41 \\
13.70 \\
\end{array}$ & $\begin{array}{l}26.89 \\
25.72 \\
20.92 \\
\end{array}$ & $\begin{array}{l}22.65 \\
14.35 \\
10.70 \\
\end{array}$ & $\begin{array}{l}22.94 \\
14.54 \\
10.82\end{array}$ & $\begin{array}{l}23.88 \\
15.31 \\
11.35 \\
\end{array}$ & $\begin{array}{l}25.42 \\
17.54 \\
12.97 \\
\end{array}$ & $\begin{array}{l}26.39 \\
24.49 \\
18.82\end{array}$ & $\begin{array}{c}21.30 \\
13.04 \\
9.620 \\
\end{array}$ & \begin{tabular}{|c|}
21.56 \\
13.18 \\
9.717 \\
\end{tabular} & $\begin{array}{r}22.44 \\
13.78 \\
10.12 \\
\end{array}$ & $\begin{array}{l}23.96 \\
15.44 \\
11.27 \\
\end{array}$ & $\begin{array}{l}25.02 \\
20.40 \\
14.83 \\
\end{array}$ \\
\hline & 0.8 & $\begin{array}{l}0.1 \\
0.5 \\
1.0\end{array}$ & $\begin{array}{l}25.51 \\
1.9 .19 \\
14.76 \\
\end{array}$ & $\begin{array}{l}25.68 \\
19.42 \\
14.90\end{array}$ & $\begin{array}{l}26.15 \\
20.29 \\
15.46 \\
\end{array}$ & $\begin{array}{l}26.69 \\
22.58 \\
17.14 \\
\end{array}$ & $\begin{array}{l}26.96 \\
26.70 \\
23.69 \\
\end{array}$ & $\begin{array}{l}24.97 \\
18.27 \\
13.88 \\
\end{array}$ & $\begin{array}{l}25.14 \\
18.47 \\
13.99 \\
\end{array}$ & $\begin{array}{l}25.61 \\
19.23 \\
14.46 \\
\end{array}$ & $\begin{array}{l}26.18 \\
21.24 \\
15.84 \\
\end{array}$ & $\begin{array}{l}26.46 \\
26.00 \\
20.90\end{array}$ & $\begin{array}{l}23.50 \\
16.01 \\
11.88\end{array}$ & $\begin{array}{l}23.67 \\
16.15 \\
11.95\end{array}$ & $\begin{array}{l}24.16 \\
16.67 \\
12.28\end{array}$ & $\begin{array}{l}24.77 \\
18.03 \\
13.13\end{array}$ & $\begin{array}{l}25.10 \\
22.08 \\
15.93\end{array}$ \\
\hline & 0.9 & $\begin{array}{l}0.1 \\
0.5 \\
1.0\end{array}$ & $\begin{array}{l}26.85 \\
26.04 \\
24.18 \\
\end{array}$ & $\begin{array}{l}26.87 \\
26.16 \\
24.38 \\
\end{array}$ & $\begin{array}{l}26.91 \\
26.47 \\
25.04 \\
\end{array}$ & $\begin{array}{l}26.96 \\
26.81 \\
26.18 \\
\end{array}$ & $\begin{array}{l}26.98 \\
26.97 \\
26.94 \\
\end{array}$ & $\begin{array}{l}26.34 \\
25.22 \\
22.05 \\
\end{array}$ & $\begin{array}{l}26.36 \\
25.36 \\
22.21 \\
\end{array}$ & $\begin{array}{l}26.41 \\
25.75 \\
22.74\end{array}$ & $\begin{array}{l}26.46 \\
26.23 \\
23.90\end{array}$ & $\begin{array}{l}26.48 \\
26.47 \\
26.30\end{array}$ & $\begin{array}{l}24.94 \\
22.15 \\
16.84\end{array}$ & $\begin{array}{l}24.97 \\
22.29 \\
16.89\end{array}$ & $\begin{array}{l}25.03 \\
22.76 \\
17.06\end{array}$ & $\begin{array}{l}25.10 \\
23.71 \\
17.49\end{array}$ & $\begin{array}{l}25.13 \\
25.04 \\
18.87\end{array}$ \\
\hline & ref. & 0.0 & \multicolumn{5}{|c|}{26.98} & \multicolumn{5}{|c|}{26,49} & \multicolumn{5}{|c|}{25,13} \\
\hline \multirow{6}{*}{2.0} & 0.5 & $\begin{array}{l}0.1 \\
0.5 \\
1.0\end{array}$ & $\begin{array}{c}18.71 \\
10.84 \\
7.973\end{array}$ & $\begin{array}{c}18.86 \\
10.89 \\
8.006 \\
\end{array}$ & $\begin{array}{l}19.53 \\
11.20 \\
8.215\end{array}$ & $\begin{array}{r}21.49 \\
12.52 \\
9.164\end{array}$ & $\begin{array}{l}24.29 \\
18.57 \\
13.78 \\
\end{array}$ & $\begin{array}{c}18.35 \\
10.56 \\
7.756 \\
\end{array}$ & $\begin{array}{c}18.50 \\
10.61 \\
7.787 \\
\end{array}$ & $\begin{array}{l}19.14 \\
10.90 \\
7.981\end{array}$ & $\begin{array}{r}21.03 \\
12.12 \\
8.851 \\
\end{array}$ & $\begin{array}{l}23.85 \\
17.49 \\
12.86 \\
\end{array}$ & $\begin{array}{l}17.36 \\
9.821 \\
7.180 \\
\end{array}$ & $\begin{array}{l}17.49 \\
9.863 \\
7.206\end{array}$ & $\begin{array}{l}18.07 \\
10.10 \\
7.366\end{array}$ & $\begin{array}{l}19.76 \\
11.08 \\
8.057\end{array}$ & $\begin{array}{l}22.63 \\
15.00 \\
10.88\end{array}$ \\
\hline & 0.6 & $\begin{array}{l}0.1 \\
0.5 \\
1.0\end{array}$ & $\begin{array}{l}19.26 \\
11.32 \\
8.340 \\
\end{array}$ & $\begin{array}{l}19.42 \\
11.37 \\
8.373 \\
\end{array}$ & $\begin{array}{r}20.08 \\
11.68 \\
8.577 \\
\end{array}$ & $\begin{array}{l}21.95 \\
12.98 \\
9.506\end{array}$ & $\begin{array}{l}24.34 \\
18.97 \\
14.06 \\
\end{array}$ & $\begin{array}{l}18.88 \\
11.01 \\
8.095\end{array}$ & $\begin{array}{l}19.03 \\
11.02 \\
8.125 \\
\end{array}$ & $\begin{array}{l}19.67 \\
11.34 \\
8.314 \\
\end{array}$ & $\begin{array}{r}21.48 \\
12.54 \\
9.161 \\
\end{array}$ & $\begin{array}{l}23.91 \\
17.83 \\
13.09 \\
\end{array}$ & $\begin{array}{l}17.84 \\
10.19 \\
7.452\end{array}$ & $\begin{array}{c}17.97 \\
10.23 \\
7.477 \\
\end{array}$ & $\begin{array}{r}18.54 \\
10.46 \\
7.630 \\
\end{array}$ & $\begin{array}{r}20.18 \\
11.41 \\
8.295 \\
\end{array}$ & $\begin{array}{l}22.70 \\
15.23 \\
11.03 \\
\end{array}$ \\
\hline & 0.7 & $\begin{array}{l}0.1 \\
0.5 \\
1.0\end{array}$ & \begin{tabular}{|c|}
20.92 \\
13.01 \\
9.652 \\
\end{tabular} & $\begin{array}{c}21.09 \\
13.07 \\
9.684 \\
\end{array}$ & \begin{tabular}{|l|}
21.72 \\
13.38 \\
9.877 \\
\end{tabular} & $\begin{array}{l}23.18 \\
14.63 \\
10.75 \\
\end{array}$ & $\begin{array}{l}24.45 \\
20.38 \\
15.08 \\
\end{array}$ & $\begin{array}{c}20.49 \\
12.57 \\
9.290 \\
\end{array}$ & $\begin{array}{l}20.65 \\
12.62 \\
9.318 \\
\end{array}$ & $\begin{array}{c}21.28 \\
12.90 \\
9.493 \\
\end{array}$ & $\begin{array}{l}22.70 \\
14.03 \\
10.27 \\
\end{array}$ & $\begin{array}{l}24.02 \\
19.04 \\
13.94\end{array}$ & \begin{tabular}{|c|}
19.28 \\
11.43 \\
8.380 \\
\end{tabular} & $\begin{array}{l}19.43 \\
11.47 \\
8.402 \\
\end{array}$ & $\begin{array}{l}19.99 \\
11.69 \\
8.536 \\
\end{array}$ & $\begin{array}{c}21.37 \\
12.55 \\
9.118 \\
\end{array}$ & $\begin{array}{l}22.83 \\
16.03 \\
11.57 \\
\end{array}$ \\
\hline & 0.8 & $\begin{array}{l}0.1 \\
0.5 \\
1.0\end{array}$ & $\begin{array}{l}23.21 \\
17.00 \\
12.89 \\
\end{array}$ & $\begin{array}{l}23.34 \\
17.08 \\
12.93 \\
\end{array}$ & $\begin{array}{r}23.71 \\
17.45 \\
13.13 \\
\end{array}$ & $\begin{array}{l}24.23 \\
18.70 \\
13.93 \\
\end{array}$ & $\begin{array}{l}24.53 \\
23.49 \\
17.79 \\
\end{array}$ & $\begin{array}{l}22.75 \\
16.18 \\
12.14 \\
\end{array}$ & $\begin{array}{l}22.87 \\
16.24 \\
12.17 \\
\end{array}$ & $\begin{array}{l}23.25 \\
16.55 \\
12.33 \\
\end{array}$ & $\begin{array}{l}23.79 \\
17.62 \\
12.99 \\
\end{array}$ & $\begin{array}{l}24.11 \\
21.93 \\
16.08 \\
\end{array}$ & $\begin{array}{l}21.44 \\
14.15 \\
10.41 \\
\end{array}$ & $\begin{array}{l}21.56 \\
14.19 \\
10.43 \\
\end{array}$ & $\begin{array}{l}21.95 \\
14.39 \\
10.54\end{array}$ & $\begin{array}{l}22.56 \\
15.11 \\
10.93\end{array}$ & $\begin{array}{l}22.94 \\
17.88 \\
12.83\end{array}$ \\
\hline & 0.9 & $\begin{array}{l}0.1 \\
0.5 \\
1.0\end{array}$ & $\begin{array}{l}24.44 \\
23.69 \\
21.74 \\
\end{array}$ & $\begin{array}{r}24.46 \\
23.78 \\
21.86 \\
\end{array}$ & $\begin{array}{l}24.50 \\
24.04 \\
22.28 \\
\end{array}$ & $\begin{array}{l}24.54 \\
24.36 \\
23.26 \\
\end{array}$ & $\begin{array}{r}24.56 \\
24.54 \\
24.48 \\
\end{array}$ & $\begin{array}{l}24.01 \\
22.93 \\
19.65 \\
\end{array}$ & $\begin{array}{l}24.03 \\
23.04 \\
19.72 \\
\end{array}$ & $\begin{array}{l}24.07 \\
23.36 \\
19.97 \\
\end{array}$ & $\begin{array}{l}24.12 \\
23.83 \\
20.63 \\
\end{array}$ & $\begin{array}{l}24.14 \\
24.12 \\
22.68 \\
\end{array}$ & $\begin{array}{l}22.81 \\
19.91 \\
14.91 \\
\end{array}$ & $\begin{array}{l}22.83 \\
19.98 \\
14.93 \\
\end{array}$ & $\begin{array}{l}22.89 \\
20.24 \\
15.00 \\
\end{array}$ & $\begin{array}{l}22.95 \\
20.86 \\
15.22 \\
\end{array}$ & $\begin{array}{l}22.98 \\
22.41 \\
16.09 \\
\end{array}$ \\
\hline & ref. & 0.0 & \multicolumn{5}{|c|}{24,56} & \multicolumn{5}{|c|}{24.14} & \multicolumn{5}{|c|}{22.98} \\
\hline
\end{tabular}






$\lambda=13.42$



$\lambda=36.01$



$\lambda=59.02$

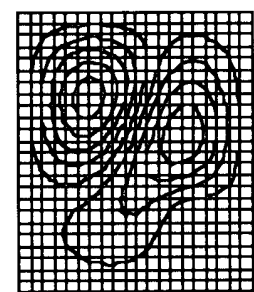

$\lambda=74.89$

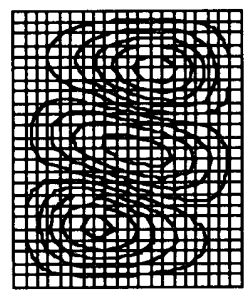

$\lambda=90.33$



$\lambda=110.7$

図-7 集中質量を有する周辺固定平板の振動モード $\left(b / a=1.2, h / a=0.05, M / a b h \rho=1.0, x_{M} / a=0.7, y_{M} / b=0.7\right)$

集中質量が固定辺の近傍に位置する場合、中央部に位置する場合に 比べて、基本振動数に及ぼす影響の少ないことが、表-2から容易に 分かる。集中質量と平板の全面に分布する全質量の比が $k=1.0$ の 值を用いて $\lambda_{P}$ の値を求め、この值と集中質量の存在しない平板の固 有振動数から、中間の值に対する固有振動数を推定補間したものを 級数解と比較した。補間值は最大誤差 $5 \%$ 以内の範囲で基本振動数 を近似表示することができ、図-6は補間式による近似状況を示した もので、ほぼ一致することが分かる。

図-7は、平板の辺長比 $b / a=1.2$ 、板厚比 $h / a=0.05$ 、質量比 $M / a b h \rho=1.0$ 、集中質量の作用位置 $x_{M} / a=0.7, y_{M} / b=0.7$ の場 合について、6次迄の固有振動モードを、この種平板の振動モード の一例として掲げたものである。

\section{5.むすび}

本報告では、平板の質量分布が自重のように平板内に一様分布す るのに加え、1 点に集中する質量が作用する場合の基本振動数に及 ぼす影響を、周辺単純支持と周辺固定の両平板について重称合せ法 を用いた級数解法を提示し、数值解析の結果を検討した。集中質量 による影響は、集中質量の存在しない平板と、特定の集中質量を有 する平板の固有振動数の両者を用いて、中間値をD unkerley式で比 較的精度よく近似表現できることを確認した。ここで提示した方法 は、質量分布が部分的に偏在する場合にも容易に拡張でき、今後、 この問題についても検討を行ってみる所存である。

\section{参考文献}

1) R. D. Mindlin: Influence of Rotatory Inertia and Shear on Flexural Motions of Isotropic, Elastic Plates, J. Appl. Mech., pp.31-38, 1951.3

2) D. J.Gorman: Pree Vibration Analys is of Rectangular Plates, Elsevier, 1982

3）内山武司：周辺単純支持Mindlin平板の自由振動解析、日本建築学会構 造系論文報告集 第418号、pp.87-95、1990.12

4）内山武司：周辺固定Mindlin平板の自由振動解析、日本建築学会 構造 工学論文集 Vol. 37B、pp. 141-150、1991.3

5）内山武司：自由辺と固定辺を有するMindlin平板の自由振動解析、日本 建築学会構造系論文報告集 第426号、pp.89-98、1991.8

8）内山武司、上田正生：带状厚板を有するMindlin平板の自由振動解析、 日本建築学会構造系論文集 第455号、pp. 17-26、1994.1

7）内山武司、上田正生：自由辺と单純支持辺を有するRe issner-Mindl in平 板の解析、日本建築学会 構造工学論文集 Vol. 42B、pp.221-231、1996

8）内山武司、上田正生：点支持を有するMindlin平板の自由振動解析、日 本建築学会構造系論文報告集 第512号、pp.83-89、1998.10

9) R. M. Liew, C.M. Wang, Y.Xiang and S. Kitipornchai : Vibration of Mindlin Plates, Elsevier, 1998

10）W. T. Thomson (小堀与一訳)：機械振動入門、丸善、昭和37年12月

11）内山武司、土橋由造：前断変形を考虑したRe issner 平板のRitz法による 解析（その 1)、日本建築学会北海道支部研究報告集(構造系) N N 0.54 、 pp. 76-79、1981.3

12）大津聡、内山武司、土橋由造 : Re issner理論による周辺固定矩形板の解 析、北海道大学工学部研究報告 第123号、pp. 77-89、昭和59年10月

付録

本報告で提示した級数解法で、採用した項数と 5 次迄の固有振動数入の収束状況を、参考のため下記の付表に示す。 付表 採用した級数の項数と 5 次迄の固有振動数 $\lambda$ の収束状況（ $\phi=b / a=1.0, \quad x_{M} / a=0.5, y_{M} / b=0.5$ ：単位 $\left.\omega=\lambda \sqrt{D / \rho h} / a^{2}\right)$

\begin{tabular}{|c|c|c|c|c|c|c|c|c|c|c|c|c|c|c|c|c|c|}
\hline & \multirow{2}{*}{$\frac{M}{a b h \rho}$} & \multirow{2}{*}{$\begin{array}{l}\text { 項 } \\
\text { 数 } \\
\end{array}$} & \multicolumn{5}{|c|}{$h / a=0.01$} & \multicolumn{5}{|c|}{$h / a=0.05$} & \multicolumn{5}{|c|}{$h / a=0.10$} \\
\hline & & & 1次 & 2次 & 3 次 & 4次 & 5 次 & 1 次 & 2次 & 3次 & 4次 & 5 次 & 1次 & 2 次 & 3次 & 4次 & 5 次 \\
\hline \multirow{2}{*}{  } & 0.1 & $\begin{array}{l}21 \\
31 \\
41 \\
51 \\
61\end{array}$ & $\begin{array}{l}16.51 \\
16.51 \\
6.51 \\
6.51 \\
6.51\end{array}$ & \begin{tabular}{l|l}
49. & 15 \\
49 & 5 \\
49.15 \\
49. & 5 \\
49. & 15
\end{tabular} & $\begin{array}{l}49.15 \\
49.15 \\
49.15 \\
49.15 \\
49.15\end{array}$ & $\begin{array}{l}75.12 \\
75.06 \\
75.03 \\
75.01 \\
75.00\end{array}$ & $\begin{array}{l}78.46 \\
78.45 \\
78.45 \\
78.45 \\
78.45\end{array}$ & $\begin{array}{l}16.08 \\
16.07 \\
16.07 \\
16.07 \\
16.07\end{array}$ & $\begin{array}{l}47.63 \\
47.63 \\
47.63 \\
47.63 \\
47.63\end{array}$ & $\begin{array}{l}47.63 \\
47.63 \\
47.63 \\
47.63 \\
47.63\end{array}$ & $\begin{array}{l}71.33 \\
71.05 \\
70.87 \\
70.72 \\
70.61\end{array}$ & $\begin{array}{l}74.68 \\
74.68 \\
74.68 \\
74.68 \\
74.68\end{array}$ & $\begin{array}{l}15.38 \\
15.37 \\
15.36 \\
15.36 \\
15.35\end{array}$ & $\begin{array}{l}44.59 \\
44.59 \\
44.59 \\
44.59 \\
44.59\end{array}$ & $\begin{array}{l}44.59 \\
44.59 \\
44.59 \\
44.59 \\
44.59\end{array}$ & $\begin{array}{l}62.83 \\
62.07 \\
61.54 \\
61.12 \\
60.77\end{array}$ & $\begin{array}{l}67.70 \\
67.70 \\
67.70 \\
67.70 \\
67.70\end{array}$ \\
\hline & 1.0 & $\begin{array}{l}21 \\
31 \\
41\end{array}$ & $\begin{array}{l}8.439 \\
8.437 \\
8.436 \\
8.436 \\
8.435 \\
\end{array}$ & $\begin{array}{l}49.15 \\
49.15 \\
49.15 \\
49.15 \\
49.15 \\
\end{array}$ & $\begin{array}{l}49.15 \\
49.15 \\
49.15 \\
49.15 \\
49.15 \\
\end{array}$ & $\begin{array}{l}56.20 \\
55.10 \\
56.06 \\
56.04 \\
56.02 \\
\end{array}$ & $\begin{array}{l}78.45 \\
78.45 \\
78.45 \\
78.45 \\
78.45 \\
\end{array}$ & $\begin{array}{l}8.210 \\
8.200 \\
8.193 \\
8.188 \\
8.184 \\
\end{array}$ & $\begin{array}{l}47.63 \\
47.63 \\
47.63 \\
47.63 \\
47.63 \\
\end{array}$ & $\begin{array}{l}47.63 \\
47.63 \\
47.63 \\
47.63 \\
47.63 \\
\end{array}$ & $\begin{array}{l}52.72 \\
52.31 \\
52.05 \\
51.84 \\
51.68 \\
\end{array}$ & $\begin{array}{l}74.68 \\
74.68 \\
74.68 \\
74.68 \\
74.68 \\
\end{array}$ & $\begin{array}{l}7.789 \\
7.759 \\
7.737 \\
7.720 \\
7.706 \\
\end{array}$ & $\begin{array}{l}44.59 \\
44.46 \\
43.85 \\
43.38 \\
43.01 \\
\end{array}$ & $\begin{array}{l}44.59 \\
44.59 \\
44.59 \\
44.59 \\
44.59 \\
\end{array}$ & $\begin{array}{l}45.37 \\
44.59 \\
44.59 \\
44.59 \\
44.59 \\
\end{array}$ & $\begin{array}{l}67.70 \\
67.70 \\
67.70 \\
67.70 \\
67.70 \\
\end{array}$ \\
\hline \multirow{2}{*}{$\begin{array}{l}\text { 周 } \\
\text { 迎 } \\
\text { 園 } \\
\text { 定 } \\
\text { 板 }\end{array}$} & 0.1 & $\begin{array}{l}21 \\
31 \\
41 \\
51 \\
61\end{array}$ & $\begin{array}{l}27.95 \\
27.94 \\
27.94 \\
27.94 \\
27.94\end{array}$ & $\begin{array}{l}73.26 \\
73.26 \\
73.26 \\
73.26 \\
73.26\end{array}$ & $\begin{array}{l}73.26 \\
73.26 \\
73.26 \\
73.26 \\
73.26\end{array}$ & $\begin{array}{c}100.2 \\
100.1 \\
99.99 \\
99.96 \\
99.94\end{array}$ & $\begin{array}{l}107.9 \\
107.9 \\
107.9 \\
107.9 \\
107.9\end{array}$ & $\begin{array}{l}27.30 \\
27.28 \\
27.27 \\
27.25 \\
27.25\end{array}$ & $\begin{array}{l}70.23 \\
70.23 \\
70.23 \\
70.23 \\
70.23\end{array}$ & $\begin{array}{l}70.23 \\
70.23 \\
70.23 \\
70.23 \\
70.23\end{array}$ & $\begin{array}{l}93.06 \\
92.55 \\
92.19 \\
91.92 \\
91.70\end{array}$ & $\begin{array}{l}101.8 \\
101.8 \\
101.8 \\
101.8 \\
101.8\end{array}$ & $\begin{array}{l}25.59 \\
25.53 \\
25.49 \\
25.46 \\
25.43\end{array}$ & $\begin{array}{l}63.04 \\
63.04 \\
63.04 \\
63.04 \\
63.04\end{array}$ & $\begin{array}{l}63.04 \\
63.04 \\
63.04 \\
63.04 \\
63.04\end{array}$ & $\begin{array}{l}78.03 \\
76.82 \\
75.96 \\
75.30 \\
74.75\end{array}$ & $\begin{array}{l}88.66 \\
88.66 \\
88.66 \\
88.66 \\
88.66\end{array}$ \\
\hline & 1.0 & $\begin{array}{l}21 \\
31 \\
41 \\
51 \\
61\end{array}$ & $\begin{array}{l}12.62 \\
12.61 \\
12.61 \\
12.61 \\
12.61\end{array}$ & $\begin{array}{l}73.26 \\
73.26 \\
73.26 \\
73.26 \\
73.26\end{array}$ & $\begin{array}{l}73.26 \\
73.26 \\
73.26 \\
73.26 \\
73.26\end{array}$ & $\begin{array}{l}81.54 \\
81.40 \\
81.31 \\
81.28 \\
81.25\end{array}$ & $\begin{array}{l}107.9 \\
107.9 \\
107.9 \\
107.9 \\
107.9\end{array}$ & $\begin{array}{l}12.26 \\
12.22 \\
12.20 \\
12.18 \\
12.16\end{array}$ & $\begin{array}{l}70.23 \\
70.23 \\
70.23 \\
70.23 \\
70.23\end{array}$ & $\begin{array}{l}70.23 \\
70.23 \\
70.23 \\
70.23 \\
70.23\end{array}$ & $\begin{array}{l}75.26 \\
74.61 \\
74.16 \\
73.84 \\
73.57\end{array}$ & $\begin{array}{l}101.8 \\
101.8 \\
101.8 \\
101.8 \\
101.8\end{array}$ & $\begin{array}{l}11.31 \\
11.20 \\
11.13 \\
11.08 \\
11.04\end{array}$ & $\begin{array}{l}62.52 \\
61.25 \\
60.39 \\
59.76 \\
59.25\end{array}$ & $\begin{array}{l}63.04 \\
63.04 \\
63.04 \\
63.04 \\
63.04\end{array}$ & $\begin{array}{l}63.04 \\
63.04 \\
63.04 \\
63.04 \\
63.04\end{array}$ & $\begin{array}{l}88.66 \\
88.66 \\
88.66 \\
88.66 \\
88.66\end{array}$ \\
\hline
\end{tabular}

